\title{
Comparative transcriptional analysis of Bacillus subtilis cells overproducing either secreted proteins, lipoproteins or membrane proteins
}

\author{
Bogumiła C Marciniak ${ }^{1 \dagger}$, Hein Trip ${ }^{1,3 \dagger}$, Patricia J van-der Veek ${ }^{1,4}$ and Oscar P Kuipers ${ }^{1,2^{*}}$
}

\begin{abstract}
Background: Bacillus subtilis is a favorable host for the production of industrially relevant proteins because of its capacity of secreting proteins into the medium to high levels, its GRAS (Generally Recognized As Safe) status, its genetic accessibility and its capacity to grow in large fermentations. However, production of heterologous proteins still faces limitations.

Results: This study aimed at the identification of bottlenecks in secretory protein production by analyzing the response of $B$. subtilis at the transcriptome level to overproduction of eight secretory proteins of endogenous and heterologous origin and with different subcellular or extracellular destination: secreted proteins (NprE and XynA of B. subtilis, Usp45 of Lactococcus lactis, TEM-1 $\beta$-lactamase of Escherichia coli), membrane proteins (LmrA of L. lactis and XyIP of Lactobacillus pentosus) and lipoproteins (MntA and YcdH of B. subtilis). Responses specific for proteins with a common localization as well as more general stress responses were observed. The latter include upregulation of genes encoding intracellular stress proteins (groES/EL, CtsR regulated genes). Specific responses include upregulation of the lialHGFSR operon under Usp45 and TEM-1 $\beta$-lactamase overproduction; CSSRS, htrA and $h t r B$ under all secreted proteins overproduction; sigW and SigW-regulated genes mainly under membrane proteins overproduction; and ykrL (encoding an HtpX homologue) specifically under membrane proteins overproduction.
\end{abstract}

Conclusions: The results give better insights into $B$. subtilis responses to protein overproduction stress and provide potential targets for genetic engineering in order to further improve B. subtilis as a protein production host.

Keywords: Protein overproduction, Secretion stress, Production host, sigW, ykrL, LiaRS, Membrane, Cell wall

\section{Introduction}

The Gram-positive bacterium B. subtilis is widely used in large scale production of endogenous and heterologous proteins used in food- and other industries. It is particularly favored as a production host since it has the capacity of secreting proteins to high levels into the medium enabling easy isolation and purification, it can be grown in large fermentations and is considered as a GRAS (Generally Recognized As Safe) organism by the US Food and Drug Administration. In addition,

\footnotetext{
* Correspondence: o.p.kuipers@rug.nl

${ }^{\dagger}$ Equal contributors

'Department of Molecular Genetics, Groningen Biomolecular Sciences and Biotechnology Institute, University of Groningen, Groningen, The Netherlands ${ }^{2}$ Kluyver Center for Genomics of Industrial Fermentation, Delft/Groningen, The Netherlands

Full list of author information is available at the end of the article
}

B. subtilis is still the most studied Gram-positive organism in fundamental research and is therefore a good model organism in the search for bottlenecks in protein overproduction. There are several cellular mechanisms that can hamper secretion of heterologous proteins on particular stages of the B. subtilis secretion pathway. At early stages of protein secretion, like synthesis of secretory pre-proteins, pre-protein interactions with cellular chaperones and binding to the translocase, the limitations may potentially result from, e.g., low transcription levels, inefficient translation, presence of intracellular proteases, deficiency in chaperones, poor targeting to the translocase, etc. [1]. The second stage of the protein secretion, i.e. translocation across the membrane via the Sec- or Tat- [2] translocase, may be confined by secretion machinery jamming [1]. At the late stages, which include removal of the 
signal peptide, release from the translocase, folding and passing the cell wall, deficiency in signal peptidases, foldases, chaperones and presence of extracellular proteases resulting in incorrect folding of proteins and protein's instability may also set limits to the secretion efficiency [1,3]. The focus on identification and later manipulation of factors involved in protein secretion have led to the improvement of $B$. subtilis as a production host, for example by deletion of extracellular and/or intracellular proteases [4-6], use of strong or inducible promoters [7-9], overproduction of chaperones $[10,11]$ or signal peptidases $[12,13]$, modification of the cell wall $[14,15]$, protein modification $[16,17]$ and deletion of stress responsive systems [18].

Next to overproduction of proteins secreted into the medium, the overproduction of membrane proteins in B. subtilis is of a particular interest [19]. Membrane proteins are potential drug targets as they are exposed to and accessible from the extracytoplasmic environment, and therefore interesting for the pharmaceutical industry. Rational drug design, however, requires a three-dimensional structure, usually obtained from protein crystals, which can only be obtained when sufficient amounts of membrane protein of high quality are available [19].

In this work, a comparative transcriptomics approach was followed to study cellular responses to secretory proteins overproduction at the transcriptional level, in order to reveal so far unidentified possible production bottlenecks and thus potential targets for productive host engineering. Endogenous and heterologous proteins with different subcellular localization, i.e. secreted proteins, membrane proteins and lipoproteins were overproduced in B. subtilis. At least two proteins of each localization were chosen, in order to be able to discriminate between effects specific for one protein and effects common to one localization class. Transcriptomes were analyzed using DNA microarrays and subsequent use of appropriate bioinformatics tools. General responses as well as responses specific to proteins with a particular localization were identified.

\section{Results and discussion}

Transcriptome analysis of lipoprotein, membrane protein or secreted protein overproduction stress

B. subtilis remains a powerful host for the (industrial) production of secreted or membrane proteins but expression of heterologous proteins in particular has met limitations. These may occur at different levels of the production and secretion pathway. Here, the response of B. subtilis on the transcriptional level to overproduction of secretory proteins of endogenous or heterologous origin and with different subcellular localization, i.e. membrane proteins, lipoproteins and secreted proteins, was determined by transcriptome analysis.

Eight genes encoding heterologous and endogenous proteins (Table 1) with different subcellular localization were cloned using the SURE system overexpression vector pNZ8902 or pNZ8901 [7]: lmrA of L. lactis, encoding the membrane embedded putative multidrug transporter LmrA [20]; xylP of Lb. pentosus encoding a membrane embedded xyloside transporter XylP [21], $m n t A$ and $y c d H$ of $B$. subtilis encoding the manganese binding lipoprotein MntA [22] and the putative zinc binding lipoprotein YcdH [23], respectively; bla of E. coli encoding the periplasm located TEM-1 $\beta$-lactamase (Bla) [24]; usp45 of L. lactis, encoding the cell wallassociated Usp45 [25]; and nprE and xynA of B. subtilis, encoding the secreted neutral protease NprE [26] and the secreted xylanase XynA [27], respectively. The genes were fused to $\mathrm{C}$-terminal $6 \mathrm{His}$-tag encoding sequences. B. subtilis NZ8900 harboring these constructs or the empty vector pNZ8902 or pNZ8901 were grown to midexponential phase and expression was induced with subtilin. Samples were taken $30 \mathrm{~min}$ after induction for microarray analyses and after two hours for testing protein production. SDS-PAGE analysis of whole-cell, membrane, cytoplasm and medium fractions together with His-tag immunodetection demonstrated that XylP, LmrA, MntA, YcdH, TEM-1 $\beta$-lactamase and Usp45 were overproduced to levels varying from high for LmrA, YcdH and Usp45 to hardly visible on a Coomassie stained gel but well detectable using immunodetection

Table 1 Proteins overproduced in B. subtilis NZ8900 host using SURE system

\begin{tabular}{|c|c|c|c|}
\hline Protein & Function & Organism & Subcellular localization \\
\hline XylP & Xyloside transporter & Lb. pentosus & Membrane \\
\hline LmrA (inactive mutant) & ABC-transporter & L. lactis & Membrane \\
\hline MntA & Manganese binding & B. subtilis & Lipoprotein \\
\hline $\mathrm{YcdH}$ & Zinc binding & B. subtilis & Lipoprotein \\
\hline XynA & Xylanase & B. subtilis & Secreted \\
\hline NprE & Neutral protease & B. subtilis & Secreted \\
\hline Usp45 & Unknown & L. lactis & Secreted \\
\hline TEM-1 $\beta$-lactamase & $\beta$-lactamase & E. coli & Secreted \\
\hline
\end{tabular}


Marciniak et al. Microbial Cell Factories 2012, 11:66

Page 3 of 13

http://www.microbialcellfactories.com/content/11/1/66

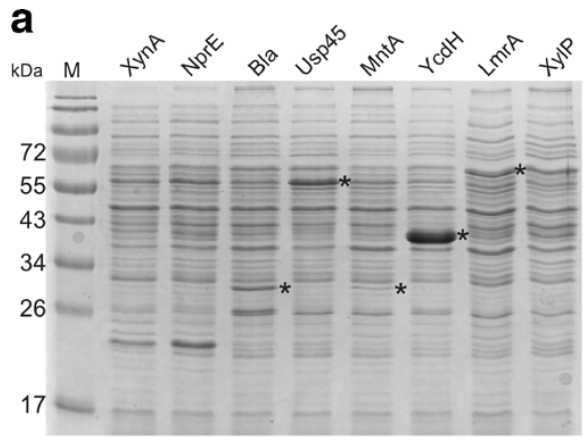

b
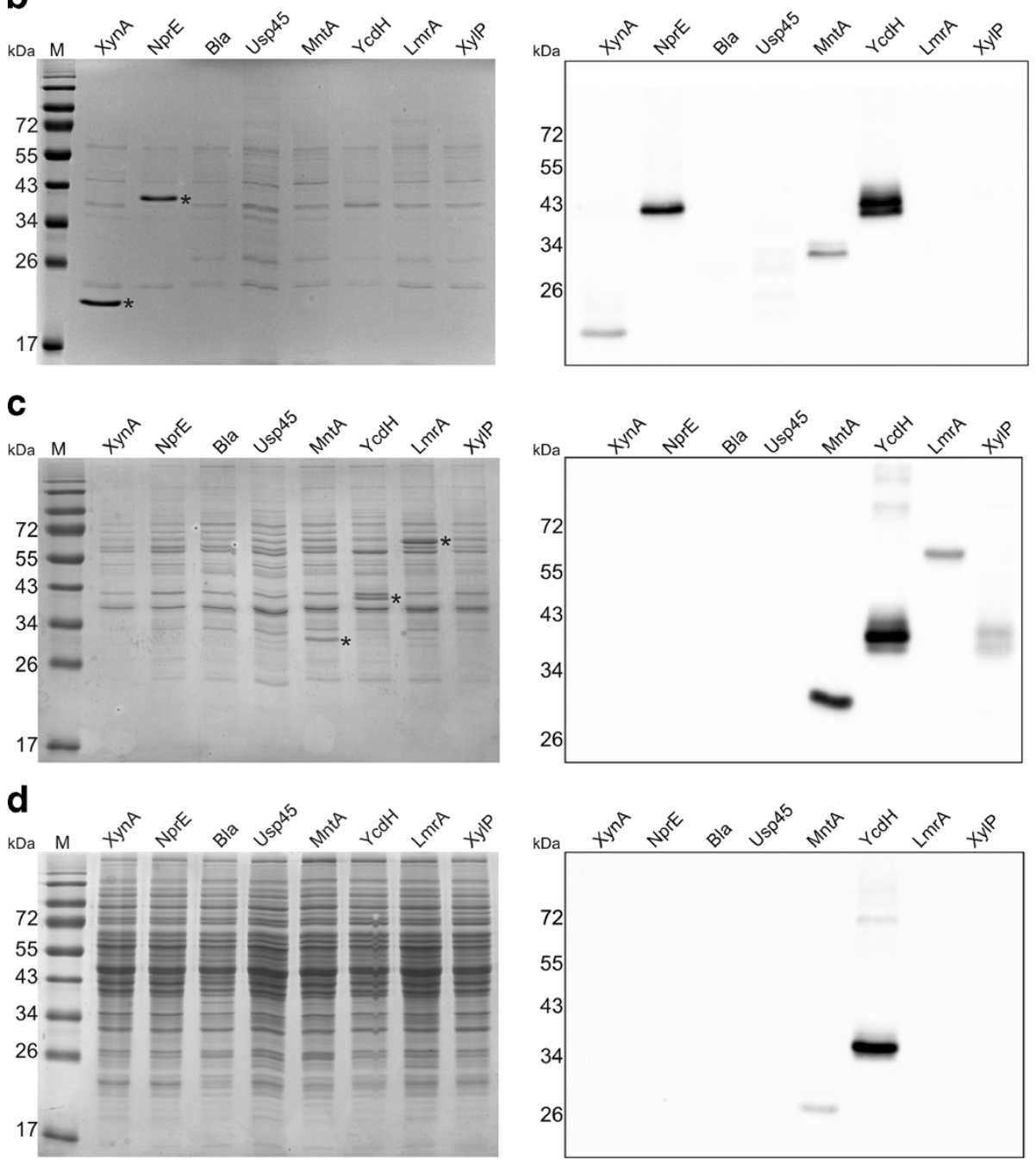

Figure 1 Overproduction of different secretory proteins in B. subtilise. (a) Whole cell extracts, (b) medium fractions, (c) membrane fractions, (d) cytoplasmic fractions. Left panels show SDS-PAGE gels; right panels (b, $\mathbf{c}$ and $\mathbf{d}$ ) show immunodetection of the 6his-tagged proteins using Penta-His HRP conjugate antibodies (Qiagen). Asterisks indicate protein bands corresponding to the overproduced proteins. Calculated molecular masses of proteins, with and without signal peptide, in RDa: XynA, 32.3 (preprotein), 20.4 (matured); Npr, 56.5 (preprotein), 53.9 (matured); BIa (TEM-1 $\beta$-lactamase), 32.3 (preprotein), 29.7 (matured); Usp45, 48.2 (preprotein), 45.5 (matured); AntA, 33.4 (preprotein), 32.4 (matured); YcdH, 36.5 (preprotein), 34.3 (matured); LIrA, 66.2; XyIP, 55.3. 
(XylP) (Figure 1). Distinct localization patterns were observed for each class of protein (Figure 1). XynA and NprE were efficiently produced and secreted into the medium (Figure 1b), whereas Usp45 and TEM-1 $\beta$ lactamase were detected mainly in whole cell fractions (Figure 1a, left panel). Since the latter two were not or hardly detectable in the cytoplasmic and membrane fractions (Figure 1c and d), it is likely that they accumulated in the cell wall or membrane-cell wall interface. In accordance, TEM-1 $\beta$-lactamase expressed in B. subtilis was previously shown to accumulate in the membrane-cell wall interface due to inefficient passage through the cell wall [28]. Usp45 shows homology with proteins involved in cell wall metabolism, e.g., peptidoglycan hydrolases of Streptococcus mutans, Streptococcus oralis, Lactococcus lactis subsp. lactis [29-31], which may explain localization in or at the cell wall. Overexpression of usp $45 \mathrm{did}$ not inhibit growth, whereas overexpression of bla resulted in growth inhibition as well as cell lysis, possibly due to interference with cell wall metabolism.

LmrA and XylP were exclusively found in the membrane fraction (Figure 1c, left and right panel). Similarly, the lipoproteins MntA and $\mathrm{YcdH}$ were present mainly in the membrane fraction, but immunodetection also indicated their presence at a low level in the medium (Figure 1b, right panel) and cytoplasmic fraction (Figure 1d, right panel). Immunodetection using His-tag antibodies proved to be of limited use in comparing levels of the different proteins, since they were detected with very different efficiencies (compare Figure 1b, left and right panel). Especially TEM-1 $\beta$-lactamase and Usp45 were hardly detectable in general.

The mRNA levels of each overproducing strain were compared with those of the control strain using DNA microarrays. Fold-changes in the expression level of genes that were at least 2.5 times up- or downregulated in response to overproduction of both proteins of the same subcellular localization, or to overproduction of at least 4 proteins with other destinations, are summarized in Table 2. Expression ratios of all the B. subtilis genes from eight microarray experiments are placed in Table S1 (Additional file 1). The complete microarray data is available at GEO repository (http://www.ncbi.nlm.nih. gov/geo/query/acc.cgi?acc=GSE34505) under accession number GSE34505.

\section{General effects}

Overproduction of all secreted proteins, except NprE, caused upregulation of class I heat-shock genes coding for molecular chaperons groES and groEL (Table 2). Overproduction of the same proteins, except for XynA and MntA, resulted in activation of class III heat-shock genes, which code for components of protease complexes (ClpXP, ClpEP, etc.) [32,33] (Table 2), and other genes regulated by CtsR, a stress and heat-shock response regulator [32]. This intracellular stress response may be caused by a high protein production rate in combination with a limited capacity in protein secretion or membrane insertion, and/or, in case of the heterologous proteins, a lower compatibility of the secretion signal with the host secretion machinery. However, accumulation of the proteins was not observed (Figure 1d). This suggests that, although the proteins were apparently secreted with good efficiency, their presence at lower levels were enough to induce the general cytoplasmic stress response. Increased expression of chaperones like GroES/EL and Clp proteases can protect the cell from toxic accumulation of mis- or unfolded protein $[34,35]$. However, high expression and activity of proteases may also set a limit for production of heterologous proteins in B. subtilis on large scale.

The $n f r A-y w c H$ operon, encoding a nitro/flavin reductase and a monooxygenase, respectively [36], was upregulated in 5 of the 8 cases (Table 2). NfrA is believed to be involved in a response to stress-induced protein damage and its corresponding gene is induced upon a wide range of stresses [37]. Therefore the coproduction of NfrA can be considered in the improvement of protein overproduction.

Another observed effect in case of most overproduced proteins was strong induction of the yhaSTU operon. It codes for a $\mathrm{K}^{+}$efflux system and has been shown to be induced by alkaline $\mathrm{pH}$, which has been suggested to be a secondary effect of compromised membrane function and bioenergetic integrity of the cell $[38,39]$, and salt stress [40].

The genes $\operatorname{tr} x A$ and $\operatorname{tr} x B$ were upregulated in the majority of the cases, without a bias towards a particular localization of the overproduced protein. $\operatorname{tr} x A$ and $\operatorname{tr} x B$ are members of Spx regulon involved in thiol-specific oxidative stress and they code for thioredoxin and thioredoxin reductase, respectively [41]. These genes are thought to be required for keeping proteins in a reduced state which, once secreted, form disulfide bonds during folding [41]. However, there was no correlation between the presence of (putative) disulfide bonds in an overproduced protein and induction of $\operatorname{tr} x A$ or $\operatorname{tr} x B$ (only TEM-1 $\beta$-lactamase, YcdH and XylP possess putative disulfide bonds, out of which overproduction of only $\mathrm{YcdH}$ resulted in $\operatorname{tr} x B$ induction). Therefore, upregulation of $\operatorname{tr} x A$ and $\operatorname{tr} x B$ is most likely induced by thiol stress as a result of secondary effects of overproduction of secretory proteins, such as a compromised membrane function.

An effect that was observed in case of all overexpressed proteins was strong downregulation of the $s d p A B C$ operon (sporulating delay protein operon) involved in production and secretion of the killing factor 
Table 2 Genes with significantly altered expression as a result of endogenous and heterologous proteins overproduction in $B$. subtilis cells ${ }^{a, b}$

\begin{tabular}{|c|c|c|c|c|c|c|c|c|}
\hline \multirow[t]{3}{*}{ Gene } & \multirow[t]{3}{*}{ Description } & \multicolumn{7}{|c|}{ Overproduced proteins } \\
\hline & & \multicolumn{2}{|c|}{ Membrane proteins } & \multicolumn{2}{|c|}{ Lipoproteins } & \multicolumn{3}{|c|}{ Secreted proteins } \\
\hline & & XyIP & LmrA & $\overline{M n t A}$ & $\mathrm{YcdH}$ & XynA & NprE & Usp45 Bla \\
\hline
\end{tabular}

\section{UPREGULATED}

\section{Cell envelope stress response}

$\begin{array}{ll}\text { cssR } & \text { two-component response regulator (class V) } \\ \text { cssS } & \text { two-component sensor histidine kinase (class V) } \\ \text { htrB } & \text { similar to HtrA-like serine protease (class V) } \\ \text { htrA } & \begin{array}{l}\text { Quality control serine protease } \\ \text { (heat-shock protein) (class V) }\end{array} \\ \text { sigM } & \text { RNA polymerase ECF-type sigma factor } \\ \text { lial (yvql) } & \text { permease } \\ \text { liaH (yvqH) } & \text { modulator of lialHGFSR (yvqlHGFEC) operon expression } \\ \text { liaG (yvqG) } & \text { hypothetical protein } \\ \text { liaF (yvqF) } & \text { integral inner membrane protein } \\ \text { liaS (yvqE) } & \begin{array}{l}\text { two-component sensor histidine kinase [YvqC] } \\ \text { sensing cell wall stress }\end{array} \\ \text { liaR (yvqC) } & \begin{array}{l}\text { two-component response regulator [YvqE] responding } \\ \text { to cell wall stress }\end{array} \\ \text { ykrL } & \text { Homolog of HtpX, membrane protease }\end{array}$

Cell envelope stress response/SigW regulon

$\begin{array}{ll}\text { sigW } & \text { RNA polymerase ECF-type sigma factor } \\ \text { rsiW (ybbM) } & \text { sigmaW anti-sigma factor } \\ \text { yuaF } & \begin{array}{l}\text { putative membrane integrity integral inner } \\ \text { membrane protein }\end{array} \\ \text { yuaG } & \text { similar to flotillin 1 } \\ \text { yual } & \text { putative acetyl-transferase } \\ \text { ydjG } & \text { putative phage replication protein } \\ \text { ydjH } & \text { hypothetical protein } \\ \text { ydjl } & \text { hypothetical protein } \\ \text { yeaA } & \text { conserved hypothetical protein } \\ \text { ydjP } & \text { similar to chloroperoxydase } \\ \text { ydjO } & \text { unknown } \\ \text { sppA } & \text { signal peptide peptidase } \\ \text { yteJ } & \text { integral inner membrane protein } \\ \text { pbpE } & \text { penicillin-binding protein 4 } \\ \text { racX } & \text { amino acid racemase } \\ \text { yaaN } & \text { hypothetical protein } \\ \text { yceC } & \text { putative stress adaptation protein } \\ \text { yceD } & \text { putative stress adaptation protein } \\ \text { yceE } & \text { putative stress adaptation protein } \\ \text { yceF } & \text { putative stress adaptation protein } \\ \text { yceG } & \text { hypothetical protein } \\ \text { yceH } & \text { hypothetical protein } \\ \text { yjoB } & \text { ATPase possibly involved in protein degradation } \\ \text { yknW } & \text { permease } \\ & \end{array}$

\begin{tabular}{|c|c|c|c|c|c|c|c|}
\hline 0.96 & 1.06 & 6.82 & 1.38 & 5.97 & 1.08 & 2.90 & 1.85 \\
\hline 0.95 & 1.11 & 3.10 & 1.54 & 2.67 & 0.99 & 2.37 & 1.66 \\
\hline 0.67 & 1.03 & 1.70 & 7.37 & 10.86 & 1.12 & 0.44 & 7.52 \\
\hline 0.76 & 1.17 & 3.17 & 5.18 & 14.88 & 0.78 & 46.70 & 7.23 \\
\hline 1.17 & 0.94 & 3.01 & 2.51 & 0.62 & 1.49 & 1.67 & 1.21 \\
\hline 2.38 & 1.07 & 1.31 & 2.55 & 1.59 & 2.03 & 8.96 & 23.44 \\
\hline 2.32 & 1.08 & 1.19 & 3.40 & 1.47 & 2.51 & 9.43 & 29.75 \\
\hline 1.48 & 1.06 & 2.27 & 2.67 & 0.82 & 2.65 & 4.55 & 13.38 \\
\hline 0.89 & 1.07 & 2.14 & 1.94 & 0.92 & 2.56 & 4.16 & 10.93 \\
\hline 1.14 & NA & 2.42 & 1.93 & 0.89 & NA & 5.88 & 6.61 \\
\hline 0.94 & 1.04 & 1.91 & 2.57 & 0.79 & 1.96 & 2.19 & 4.76 \\
\hline 10.35 & 3.62 & 1.66 & 0.88 & 2.15 & 0.90 & 2.98 & 1.85 \\
\hline 4.52 & 5.50 & 1.95 & 1.77 & 1.62 & 1.05 & 1.73 & 2.44 \\
\hline 5.54 & 4.11 & 2.43 & 1.72 & 2.31 & 0.84 & 1.89 & 2.61 \\
\hline 6.93 & 2.65 & 1.09 & 0.23 & 1.41 & 1.31 & 2.15 & 2.36 \\
\hline 12.21 & 3.43 & 0.66 & 0.75 & 1.87 & 1.00 & 4.52 & 2.40 \\
\hline 15.16 & 6.62 & 0.40 & 0.81 & 2.80 & 0.78 & 5.01 & 2.70 \\
\hline 7.70 & 2.85 & 0.59 & 1.85 & 1.93 & 1.01 & 3.09 & 1.46 \\
\hline 6.88 & 3.92 & 0.60 & 0.48 & 1.68 & 1.09 & 2.19 & 1.86 \\
\hline 6.78 & 4.55 & 0.59 & 0.75 & 1.86 & 0.57 & 2.84 & 2.40 \\
\hline 5.58 & 3.28 & 0.93 & 0.42 & 1.41 & 2.36 & 1.35 & 2.10 \\
\hline 7.41 & 4.67 & 1.16 & 0.91 & 2.55 & 1.53 & 4.56 & 3.00 \\
\hline 3.81 & 7.59 & 1.14 & 1.08 & 1.99 & 1.46 & 2.97 & 2.57 \\
\hline 4.25 & 3.12 & 0.33 & 0.26 & 1.18 & 0.39 & 1.70 & 1.80 \\
\hline 4.48 & 4.16 & 0.31 & 0.29 & 1.27 & 0.34 & 2.27 & 1.77 \\
\hline 11.25 & 8.56 & 0.95 & 0.97 & 2.08 & 0.49 & 6.37 & 2.72 \\
\hline 8.99 & 8.09 & 0.78 & 0.95 & 2.06 & 0.45 & 6.00 & 2.39 \\
\hline 4.03 & 6.82 & 1.07 & 0.43 & 1.15 & 2.64 & 1.51 & 1.82 \\
\hline 2.44 & 3.05 & 2.06 & NA & NA & 0.54 & NA & 1.64 \\
\hline 5.29 & 7.02 & 0.81 & 0.76 & 2.04 & 0.92 & 3.14 & 1.55 \\
\hline 4.55 & 5.36 & 0.82 & 0.67 & 2.08 & 0.89 & 3.71 & 2.34 \\
\hline 5.30 & 4.91 & 0.70 & 0.78 & 2.07 & 0.73 & 4.27 & 1.79 \\
\hline 3.99 & 3.02 & 0.79 & 1.07 & 1.94 & 1.04 & 3.29 & 1.22 \\
\hline 3.72 & 4.09 & 0.64 & 0.99 & 1.99 & 0.60 & 3.68 & 2.15 \\
\hline 7.16 & 2.98 & 1.28 & 0.65 & 1.45 & 0.94 & 1.74 & 2.44 \\
\hline 2.51 & 3.06 & 0.67 & 0.36 & 1.12 & 0.84 & 1.14 & 1.46 \\
\hline
\end{tabular}


Table 2 Genes with significantly altered expression as a result of endogenous and heterologous proteins overproduction in $\mathbf{B}$. subtilis cells ${ }^{a, b}$ (Continued)

\begin{tabular}{|c|c|c|c|c|c|c|c|c|c|}
\hline$y k n Y$ & ABC transporter ATP-binding protein & 2.63 & 2.54 & 0.49 & 0.33 & 1.31 & 0.57 & 1.51 & 1.64 \\
\hline ythQ & putative $A B C$ transporter (permease) & 10.01 & 5.75 & 0.80 & NA & 2.21 & NA & 3.21 & 3.19 \\
\hline yqfB & hypothetical protein & 6.37 & 6.24 & 1.12 & 0.56 & 1.66 & 0.39 & 3.10 & 2.93 \\
\hline$y v / A$ & hypothetical protein & 4.11 & 3.06 & 1.49 & 0.59 & 1.23 & 1.34 & 1.39 & 2.04 \\
\hline$y v / B$ & hypothetical protein & 6.13 & 9.56 & 0.99 & 0.66 & 1.76 & 0.91 & 3.84 & 2.10 \\
\hline$y v / C$ & putative regulator (stress mediated) & 3.83 & 7.71 & 0.99 & 0.61 & 1.61 & 0.76 & 2.24 & 2.05 \\
\hline$y v \mid D$ & putative integral inner membrane protein & 4.26 & 6.66 & 1.60 & 0.65 & 1.22 & 0.74 & 2.98 & 1.87 \\
\hline$y \times j l$ & unknown & 10.12 & 5.20 & 0.96 & 0.55 & 1.60 & 1.46 & 1.38 & 1.83 \\
\hline \multicolumn{10}{|c|}{ Intracellular stress response } \\
\hline $\operatorname{hrcA}$ & transcriptional repressor of class I heat-shock genes & 11.08 & 2.23 & 1.89 & 12.62 & 0.96 & 1.30 & 2.33 & 2.12 \\
\hline groES & class I heat-shock protein (chaperonin) & 8.37 & 7.17 & 0.10 & 6.85 & 3.15 & 1.11 & 3.68 & 3.07 \\
\hline groEL & class I heat-shock protein (chaperonin) & 8.38 & 4.17 & 0.35 & 5.07 & 2.73 & 1.14 & 3.00 & 2.66 \\
\hline$n f r A$ & $\begin{array}{l}\text { FMN-containing NADPH-linked nitro/flavin } \\
\text { reductase (class VI) }\end{array}$ & 7.36 & 3.32 & 0.47 & 1.67 & 10.37 & 0.98 & 13.77 & 1.85 \\
\hline$y w c H$ & putative monooxygenase (class VI) & 10.29 & 2.91 & 1.04 & 6.03 & 5.29 & 0.86 & NA & 2.46 \\
\hline $\operatorname{trx} B$ & thioredoxin reductase & 4.71 & 1.59 & 0.88 & 2.98 & 3.97 & 0.72 & 3.56 & 1.36 \\
\hline $\operatorname{trx} A$ & thioredoxin & 2.29 & 1.94 & 0.86 & 1.68 & 3.08 & 1.13 & 3.11 & 1.31 \\
\hline $\operatorname{cts} R$ & transcriptional regulator of class III stress genes & 0.71 & 0.55 & 1.39 & NA & NA & NA & NA & NA \\
\hline mCsA & modulator of CtsR repression & 10.38 & 3.47 & 0.87 & 5.12 & 1.72 & 1.57 & 4.63 & 3.11 \\
\hline$m c s B$ & modulator of CtsR repression & 6.92 & 4.11 & 0.83 & 5.09 & 2.46 & 1.09 & 2.68 & 2.63 \\
\hline$c l p C$ & class III stress response-related ATPase & 5.65 & 3.24 & 0.65 & 4.63 & 2.03 & 0.80 & 3.28 & 2.80 \\
\hline $\operatorname{rad} A$ & DNA repair protein & 2.79 & 1.97 & 0.75 & 3.86 & 1.82 & 1.26 & 3.14 & 2.19 \\
\hline$c \mid p E$ & Class III, ATP-dependent Clp protease-like & 74.08 & 1.89 & 0.98 & 4.54 & 0.77 & 1.24 & 5.95 & 4.79 \\
\hline \multicolumn{10}{|c|}{ Membrane bioenergetics } \\
\hline$f d h D$ & required for formate dehydrogenase activity & 2.89 & 1.26 & 2.99 & 4.65 & 1.93 & 1.65 & 1.67 & 0.94 \\
\hline$c y d B$ & cytochrome bd ubiquinol oxidase (subunit II) & 0.75 & 2.28 & 1.39 & 0.51 & 2.93 & 4.50 & 0.74 & 0.64 \\
\hline \multicolumn{10}{|c|}{ Miscellaneous } \\
\hline kinD & TCS sensor histidine kinase; initiation of sporulation & 1.35 & 1.20 & 3.18 & 2.76 & 1.49 & 1.81 & 1.05 & 1.05 \\
\hline yabT & putative serine/threonine-protein kinase & 2.19 & 1.14 & NA & 1.56 & 2.55 & 2.65 & 1.26 & 1.04 \\
\hline ycek & putative transcriptional regulator (ArsR family) & 2.58 & 2.54 & 0.81 & 1.35 & 1.07 & 1.06 & 2.10 & 1.92 \\
\hline yjbl & putative thiol management oxidoreductase component & 3.93 & 0.99 & 1.45 & 2.95 & 3.23 & 1.33 & 3.61 & 1.46 \\
\hline yloc & unknown & 1.65 & 1.09 & 3.56 & 3.51 & 1.47 & 1.36 & 1.57 & 1.05 \\
\hline ynd $N$ & fosfomycin resistance protein FosB & 6.66 & 13.17 & 0.94 & 0.32 & 1.60 & 0.56 & 3.49 & 3.04 \\
\hline yrkA & putative membrane associated protein & 3.20 & 3.75 & 1.51 & 0.96 & 1.48 & 0.97 & 1.13 & 1.30 \\
\hline$y v d T$ & $\begin{array}{l}\text { uncharacterized transcriptional regulator } \\
\text { (TetR/AcrR family) }\end{array}$ & 2.94 & 3.28 & 1.82 & 2.19 & 1.37 & 1.80 & 2.26 & 1.92 \\
\hline$y v d S$ & $\begin{array}{l}\text { similar to molecular chaperone, putative } \\
\text { membrane protein }\end{array}$ & 7.12 & 2.12 & 1.20 & 1.14 & 1.08 & 1.26 & 3.43 & 1.96 \\
\hline$y v d R$ & similar to molecular chaperone, putative membrane protein & 6.32 & 2.66 & 2.46 & 1.39 & 1.01 & 1.36 & 3.99 & 1.81 \\
\hline \multicolumn{10}{|c|}{ Transport/binding proteins } \\
\hline $\operatorname{cyd} \mathrm{d}$ & ABC membrane transporter ATP-binding protein & 3.22 & 3.76 & 0.87 & 0.32 & 2.92 & 2.36 & 2.25 & 1.12 \\
\hline yhat & $\mathrm{K}+/ \mathrm{H}+$ antiporter for $\mathrm{K}+$ efflux & 15.45 & 3.48 & 2.16 & 2.91 & 2.47 & 1.22 & 4.80 & 2.54 \\
\hline yhaU & $\mathrm{K}+/ \mathrm{H}+$ antiporter for $\mathrm{K}+$ efflux & 15.49 & 2.19 & 2.38 & 1.84 & 2.56 & 1.00 & 5.14 & 1.97 \\
\hline \multicolumn{10}{|c|}{ Unknown } \\
\hline ydiN & unknown & 4.44 & 2.76 & 0.22 & 5.11 & 1.75 & 1.75 & 2.41 & 3.51 \\
\hline yomP & hypothetical protein & 3.57 & 3.21 & 0.92 & 3.33 & 0.89 & 2.60 & 1.40 & 0.82 \\
\hline
\end{tabular}


Table 2 Genes with significantly altered expression as a result of endogenous and heterologous proteins overproduction in B. subtilis cells ${ }^{a, b}$ (Continued)

\begin{tabular}{|c|c|c|c|c|c|c|c|c|c|}
\hline yomT & hypothetical protein & 2.92 & 2.60 & 0.83 & 2.90 & 0.72 & 2.47 & 1.24 & 0.85 \\
\hline ycel & putative transporter & 2.92 & 3.55 & 1.49 & 0.80 & 1.75 & 0.69 & 2.89 & 2.26 \\
\hline yhas & $\mathrm{K}+/ \mathrm{H}+$ antiporter for $\mathrm{K}+$ efflux & 9.48 & 2.13 & 2.08 & 1.76 & 2.42 & 0.96 & 3.41 & 1.94 \\
\hline yomV & hypothetical protein & 3.59 & 3.37 & 1.05 & 3.92 & 0.73 & 2.55 & 1.43 & 0.88 \\
\hline yomW & hypothetical protein & 3.19 & 3.38 & 0.97 & 4.57 & 0.65 & 2.79 & 1.31 & 0.78 \\
\hline yomY & hypothetical protein & 3.66 & 2.53 & 1.09 & 3.64 & 0.77 & 2.60 & 1.66 & 0.82 \\
\hline yon $B$ & hypothetical protein & 3.22 & 2.92 & 0.96 & 2.61 & 1.01 & 2.26 & 1.24 & 0.79 \\
\hline yonc & hypothetical protein & 2.92 & 2.64 & 0.83 & 2.84 & 0.96 & 2.41 & 1.43 & 0.84 \\
\hline$y v k N$ & hypothetical protein & 3.21 & 2.69 & 0.89 & 0.61 & 1.83 & 1.07 & 1.88 & 1.69 \\
\hline$y w m B$ & hypothetical protein & 1.32 & 1.18 & 3.00 & 2.67 & 1.30 & 2.43 & 0.55 & 1.16 \\
\hline \multicolumn{10}{|c|}{ DOWN REGULATED } \\
\hline \multicolumn{10}{|c|}{ Starvation response } \\
\hline sdpA (yvaW) & export of killing factor SdpC & 15.28 & 2.78 & 4.29 & 3.96 & 3.54 & 1.54 & 14.19 & 4.35 \\
\hline $\operatorname{sdp} B(y v a X)$ & exporter of killing factor $\mathrm{SdpC}$ & 19.87 & 4.06 & 3.26 & 5.34 & 3.96 & 1.49 & 13.85 & 4.00 \\
\hline$s d p C(y v a Y)$ & killing factor SdpC & 8.12 & 2.75 & 2.45 & 12.90 & 11.51 & 1.21 & 26.62 & 5.56 \\
\hline \multicolumn{10}{|c|}{ Cell envelope stress/SigW regulon } \\
\hline sppA & signal peptide peptidase & 0.24 & 0.32 & 3.03 & 3.89 & 0.85 & 2.56 & 0.59 & 0.56 \\
\hline yteJ & putative integral inner membrane protein & 0.22 & 0.24 & 3.18 & 3.51 & 0.79 & 2.93 & 0.44 & 0.56 \\
\hline \multicolumn{10}{|c|}{ Transport/binding proteins and lipoproteins } \\
\hline gltt & proton/sodium-glutamate symport protein & 3.36 & 3.12 & 2.52 & 1.63 & 0.82 & 1.96 & 8.35 & 1.20 \\
\hline pbux & xanthine permease & 3.32 & 2.74 & 0.45 & 1.76 & 1.47 & 1.50 & 4.45 & 1.61 \\
\hline yhaQ & $\mathrm{Na}+-$-effluxABCtransporterATP-bindingprotein & 2.07 & 1.55 & 3.73 & 4.51 & 2.19 & 2.10 & 1.65 & 1.32 \\
\hline yoaG & putative permease & 0.13 & 0.67 & 3.13 & 3.68 & 1.20 & 1.15 & 0.66 & 0.53 \\
\hline \multicolumn{10}{|c|}{ Membrane bioenergetics } \\
\hline$c t a B$ & cytochrome caa3 oxydase assembly factor & 1.18 & 1.63 & 0.66 & 1.16 & 1.34 & 1.15 & 3.48 & 1.17 \\
\hline $\mathrm{ctaC}$ & cytochrome caa3 oxidase subunit II & 4.37 & 1.13 & 4.74 & 2.68 & 1.08 & 1.91 & 5.52 & 1.20 \\
\hline$c t a D$ & cytochrome caa3 oxidase subunit I & 3.71 & 1.37 & 3.58 & 3.14 & NA & 1.81 & 3.33 & 1.27 \\
\hline ctaE & cytochrome caa3 oxidase subunit III & 3.57 & 1.44 & 2.40 & 3.02 & 1.90 & 2.08 & 4.21 & 1.10 \\
\hline ctaF & cytochrome caa3 oxidase subunit IV & 4.33 & 1.91 & 2.05 & 3.86 & 2.68 & 2.32 & 4.24 & 1.41 \\
\hline$c t a G$ & cytochrome aa3 assembly factor & 4.61 & NA & 2.40 & 1.83 & NA & 1.19 & 2.67 & NA \\
\hline \multicolumn{10}{|c|}{ Miscellaneous } \\
\hline$b d b B$ & bacteriophage SPbeta thiol-disulfide oxidoreductase & 3.59 & 2.79 & 6.00 & 2.57 & 3.05 & 1.16 & 14.00 & 2.00 \\
\hline wapA & cell wall-associated protein precursor & 2.88 & 1.07 & 1.15 & 8.19 & 2.50 & 0.91 & 6.38 & 1.15 \\
\hline$y \times x G$ & hypothetical protein & 4.04 & 0.99 & 1.22 & 8.68 & 4.20 & 0.87 & 5.25 & 1.08 \\
\hline wprA & cell wall-associated protease & 2.45 & 1.05 & 4.87 & 4.19 & 2.27 & 1.85 & 9.13 & 1.27 \\
\hline \multicolumn{10}{|l|}{ Unknown } \\
\hline yisL & hypothetical protein & 2.00 & 1.13 & 2.58 & 4.59 & 1.41 & 1.96 & 0.73 & 1.11 \\
\hline yokE & hypothetical protein & 1.56 & 1.76 & 7.19 & 2.84 & 2.74 & 1.50 & 4.35 & 1.28 \\
\hline$y t x G$ & hypothetical protein & 1.80 & 0.76 & 2.98 & 2.56 & 0.83 & 1.00 & 0.48 & 0.93 \\
\hline yukE & hypothetical protein & 1.37 & 1.56 & 3.25 & 2.67 & 0.92 & 2.04 & 1.60 & 1.02 \\
\hline$y \times b C$ & hypothetical protein & 3.55 & 0.69 & 3.22 & 5.71 & 0.72 & 1.30 & 2.06 & 1.11 \\
\hline
\end{tabular}

${ }^{a}$ Significant changes ( $\mathrm{p}$ value $<0.01$, fold $>2.5$ ) are shown in bold.

${ }^{b}$ Endogenous proteins: MntA, YcdH, XynA, NprE; heterologous proteins: XyIP (Lb. pentosus), LmrA and Usp45 (L. lactis), Bla (TEM-1 $\beta$-lactamase, E. coli). 
SdpC (Table 2). It plays a role in programmed cell death (PCD), a mechanism of sporulation delay by killing nonsporulating siblings and feeding on the dead cells under conditions of nutrient limitation $[42,43]$. This effect may be related to nutrient limitation which was shown to induce the sporulation process in a subpopulation of a $B$. subtilis culture with concomitant activation of the $s d p A B C$ and $s d p R I$ immunity operons [43].

Another general effect, but less pronounced than for $s d p A B C$, was downregulation of the ctaCDEF genes coding for cytochrome $c$ oxidase caa3 [44].

Overproduction of none of the proteins caused upregulation of genes coding for components of the secretion (Sec) machinery, like $\sec A$, secDF, ffh, etc., which are responsible for translocation of unfolded pre-proteins across or insertion into the membrane (for review see [2]). Apparently, increasing its protein secretion capacity is not a strategy of the cell to deal with an accumulation of secretory proteins. This may indicate either that the SecYEG channel does not form a bottleneck in secretion in the experiments performed here, or that expression of the genes encoding the SecYEG components is simply not upregulated by (the consequences of) an artificially imposed overproduction of secretory proteins. The latter suggests that SecYEG should not necessarily be excluded as a potential target for production strain improvement. In agreement, overexpression of $\operatorname{prs} A$, encoding the extracellular foldase PrsA, was shown to increase the secretion of an $\alpha$-amylase fourfold [10], while prsA was not upregulated in any of the tested cases here. This however does not detract from the value of the data as a source of new potential targets for strain improvement. For some of these genes, induced by overexpression of many of the tested secretory proteins, it was indeed shown previously that either their deletion or overexpression improved specific protein production yields, e.g., sigW and cssRS [18] and genes encoding intracellular chaperones [5].

\section{Proteins with extracytosolic destination induce the CssRS mediated secretion stress response}

Overproduction of the secreted protein XynA of B. subtilis, the cell wall-associated proteins Usp45 of L. lactis and TEM-1 $\beta$-lactamase of E. coli, as well as lipoproteins MntA and $\mathrm{YcdH}$ of $B$. subtilis resulted in significant upregulation of the secretion stress genes $h \operatorname{tr} A, h \operatorname{tr} B$ and cssRS (Table 2). CssR and CssS encode a response regulator and its cognate, membrane embedded sensor, respectively, and control the expression of $h \operatorname{tr} A$ and $h \operatorname{tr} B$ $[45,46]$. These encode membrane-anchored HtrA and HtrB proteins, which have their active site on the trans side of the membrane and are thought to have proteolytic as well as chaperone activity for removal of misfolded protein or for assisting in folding of newly secreted proteins, respectively [47]. The CssRS two component system is activated by accumulation of mis- or unfolded secreted protein at the membrane - cell wall interface, as a result of, e.g., overexpression of these proteins or heat stress $[48,49]$. In this study, overproduction of the membrane proteins LmrA and XylP did not significantly induce $h \operatorname{tr} A$ or $h \operatorname{tr} B$. This is in agreement with previous results from an analysis of the activation of the htr $A$ promoter in response to overproduction of secretory proteins, including MntA, XynA, TEM-1 $\beta$-lactamase, Usp45 and LmrA, showing that the stress signal is sensed on the outside of the cell and not from within the membrane [48]. Surprisingly, NprE overproduction did not induce the CssRS response. Possibly, NprE can be produced and secreted to high levels without accumulation of misfolded protein.

\section{Usp45 and TEM-1 $\beta$-lactamase specifically induce the LiaRS-dependent response}

The two proteins which were detected mainly in the whole cell fractions, but not in the membrane and cytoplasmic fractions, Usp45 and TEM-1- $\beta$-lactamase (Figure 1), specifically induced the liaIHGFSR (yvqIHGFEC) operon (Table 2), a cell envelope stress operon which is under control of the LiaRS (YvqCE) twocomponent system [50-53]. The fact that LiaRS is strongly induced by cell wall-active antibiotics [54], suggests that Usp45 and TEM1- $\beta$-lactamase had accumulated in or at the cell wall, as noted earlier, and thereby interfered with cell wall metabolism. Since the other secretory proteins did not, or to a much lesser extent, induce LiaRS (Table 2), it appears that the signal which is sensed by the sensor LiaS originates from cell wall metabolism related processes, rather than for example cell membrane integrity.

\section{Membrane protein overproduction induces a SigW response and $y k r L$ expression}

The overproduction of the membrane proteins LmrA and XylP and to a lesser extent the cell wall-associated proteins Usp45 and TEM-1 $\beta$-lactamase caused significant upregulation of sigW and many genes belonging to the SigW regulon (Table 2). The SigW regulon has been shown to be induced by a variety of cell envelope stresses like treatment with detergents (Triton X-100), antibiotics (vancomycin, penicillin) [51], alkaline stress [55] or membrane protein overproduction [18]. Activation of SigW depends on proteolytic degradation of the antiSigmaW factor RsiW by a multipass membrane protease, PrsW and, subsequently, other proteases [56,57], but the exact signal triggering this cascade is not known. The induction by membrane protein overexpression suggests that the stress signal is sensed from within the membrane. 
Next to the SigW response, an unknown gene, $y k r L$, was significantly upregulated under LmrA and XylP overproduction (Table 2). YkrL shows high homology to the E. coli HtpX, a membrane embedded metalloprotease, which has been implied in membrane protein quality control [58]. The upregulation of $y k r L$ suggests a similar role in $B$. subtilis. It would be of interest to test the effect of different levels of YkrL on the level and quality of overproduced membrane proteins. Expression of $h t p X$ in $E$. coli is regulated by the CpxRA two component system that regulates a number of genes involved in cell envelope stress, including $\operatorname{deg} P$ (or $h t r A$ ), encoding a close homologue of B. subtilis HtrA and HtrB [59]. Here, no correlation between expression of the CssRS targets and $y k r L$ was observed, suggesting that $y k r L$ expression does not depend on CssRS and is regulated differently from $h t p X$ in $E$. coli.

In $E$. coli, the membrane located ATP-dependent metalloprotease FtsH is involved in the membrane protein stress response [60]. A similar role of B. subtilis $\mathrm{FtsH}$, sharing $47 \%$ identity with E. coli $\mathrm{FtsH}$, was suggested before [19]. However, ftsH was not significantly upregulated in response to overproduction of membrane proteins or to any of the other secretory proteins. Previous results revealing the sporulation control proteins SpoVM and SpoOE as substrates of FtsH [61,62] may therefore be examples of a more specific role of $\mathrm{FtsH}$ in B. subtilis, rather than a general protein quality control system.

An operon of unknown function, $y v d T S R$, encoding a putative transcriptional regulator and two membrane proteins with homology to small multidrug resistance (SMR) proteins, was also specifically upregulated, but its role in membrane stress is unclear.

Like in case of the other secretory proteins, overproduction of LmrA and XylP led to induction of the class I heat shock protein genes groES, groEL and class III heat shock protein genes, e.g., $\operatorname{clp} E, \operatorname{clp} C$, which suggests that some fraction of overproduced membrane proteins is targeted by chaperones or proteases for degradation in the cytoplasm before translocation through the Sec machinery and insertion into the membrane. Alternatively, a protein that is incorrectly inserted into the membrane may be subject to Clp-mediated proteolysis, although it is not known whether membrane embedded proteins are accessible to Clp complexes.

\section{Other extracytoplasmic function (ECF) sigma factors}

Next to the SigW response, induced by overproduction of the LmrA, XylP, Usp45 and TEM-1 $\beta$-lactamase, upregulation of SigM and SigY RNA polymerase ECF (extracytoplasmic function)-type sigma factors, was observed in some cases (Table 2). SigM has been shown to be involved in a response to salt, low $\mathrm{pH}$, ethanol, heat and oxidative stress and cell wall synthesis inhibiting antibiotics $[63,64]$. In this study, sigM was upregulated under conditions of overproduction of the lipoproteins MntA and YcdH. However, known SigM targets [65] were not upregulated. Expression of SigY and some of the SigY target genes [66] was induced upon XylP and Usp45 overproduction.

\section{Conclusions}

This comparative study revealed differential responses of B. subtilis to stress caused by overproduction of secretory proteins with different subcellular localization. New insights in (specificity of) stress responses, in particular at the membrane and cell wall level were obtained. The data reveal possible bottlenecks in the protein production process, which can be targeted in the future development of the improved production strains.

\section{Methods}

\section{Bacterial strains and growth conditions}

Bacterial strains and plasmids used in this study are listed in Table 3. L. lactis NZ9000 [67] was used as intermediate cloning hosts for pNZ8901 and pNZ8902 based vectors. B. subtilis strains were grown in TY medium [68] at $37^{\circ} \mathrm{C}$ with vigorous shaking. TY medium was supplemented with kanamycin $(5 \mu \mathrm{g} / \mathrm{ml})$, erythromycin $(0.5 \mu \mathrm{g} / \mathrm{ml})$ or chloramphenicol $(5 \mu \mathrm{g} / \mathrm{ml})$ when needed. L. lactis strains were transformed by electroporation as described before [69] using a Bio-Rad gene pulser (BioRad Laboratories, Richmond, California). B. subtilis strains were transformed as described before [70].

\section{Plasmid and strain construction}

Molecular techniques were carried out as described before [71]. All primers used in this study are listed in Table 4. To construct overexpression vectors, the genes $n p r E$, bla, $y c d H$ and $x y l P$ were amplified using primers nprE-fw and nprE-rv, bla_F and bla_R, ycdH-Fw and ycdH-rv, xylP-fw and xylP-rv, respectively. Template DNA for amplification of $n p r E$ and $y c d H$ was B. subtilis chromosomal DNA. The bla gene was amplified from pUC18 plasmid DNA [72] and $x y l P$ from chromosomal DNA of $L b$. pentosus. The PCR products of bla and $x y l P$ were digested with $P a g \mathrm{I}$ and $X b a \mathrm{I}$ and ligated to pNZ8902, which was digested with NcoI and XbaI, resulting in pNZ-bla and pNZ-xylP. The nprE PCR product was digested with $\mathrm{NcoI}$ and $\mathrm{XbaI}$ and ligated to pNZ8901 digested with the same enzymes, resulting in pNZ-nprE. The $y c d H$ PCR product was digested with BstEII and XbaI and ligated to pNZ8902 digested with the same enzymes, yielding pNZ-ycdH. Restriction enzymes were obtained from Fermentas. The sequences of all constructs were confirmed by DNA sequence analysis (ServiceXS, Leiden, The Netherlands). 
Table $\mathbf{3}$ List of strains and plasmids used in this study

\begin{tabular}{lll}
\hline Strain/plasmid & Description & Reference \\
\hline L. lactis & MG1363 derivative, pepN::nisRK & {$[67]$} \\
NZ9000 & & \\
B. subtilis & 168, amyE::spaRK, KanR, \\
NZ8900 & SURE expression system host & {$[7]$} \\
& & \\
Plasmids & SURE expression vector, PspaSpn, CmR & {$[7]$} \\
pNZ8901 & SURE expression vector, PspaSpn, EmR & {$[7]$} \\
pNZ8902 & pNZ8902 carrying xynA of B. subtilis & {$[48]$} \\
pNZ-xynA & pNZ8902 carrying usp45 of L. lactis MG1363 & {$[48]$} \\
pNZ-usp45 & pNZ8902 carrying mntA of B. subtilis & {$[48]$} \\
pNZ-mntA & pNZ8902 carrying ImrA of L. lactis MG1363 & {$[48]$} \\
pNZ-ImrA & pNZ8901 carrying nprE of B. subtilis & This work \\
pNZ-nprE & pNZ8902 carrying bla of E. coli, & This work \\
pNZ-bla & pNZ8902 carrying ycdH of B. subtilis & This work \\
pNZ-ycdH & pNZ8902 carrying xyIP of Lb. pentosus & This work \\
pNZ-xyIP & &
\end{tabular}

\section{DNA microarray analysis}

The overexpressed endogenous proteins were XynA, NprE, MntA and YcdH (Table 1). The overexpressed heterologous proteins were TEM-1 $\beta$-lactamase from $E$. coli, Usp45 and LmrA (inactive mutant) from L. lactis and XylP from $L b$. pentosus (Table 1). For the overproduction of the proteins, the SURE overexpression system was used [7]. The transcription profile of the control B. subtilis strain NZ8900 with empty pNZ8902 vector was compared to an isogenic target strain carrying one of the overexpression constructs: pNZ-xynA, pNZ-bla, pNZ-usp45, pNZ-mntA, pNZ-ycdH, pNZlmrA or pNZ-xylP. The target strain containing pNZnprE was compared to NZ8900 carrying empty pNZ8901. In total, eight independent microarray experiments were conducted.

Strains harbouring overexpression constructs or the empty vectors pNZ8901 or pNZ8902 were grown overnight in $10 \mathrm{ml}$ TY broth supplemented with appropriate antibiotics and diluted the next day in $50 \mathrm{ml}$ of fresh medium to an $\mathrm{OD}_{600}$ of 0.05 . At an $\mathrm{OD}_{600}$ of 0.6, $0.1 \%$ ( $\mathrm{vol} / \mathrm{vol}$ ) subtilin-containing supernatant of B. subtilis strain ATCC 6633 [73] was added to the growth medium to induce gene expression. After $30 \mathrm{~min}, 10$ OD units of each culture were collected for RNA isolation. All the microarray experiments were performed in three biological replicates essentially as described before [74]. Total RNA was isolated using a High Pure RNA isolation Kit (Roche Applied Science). RNA quantity and quality were tested with a Nano Drop ND-1000 spectrophotometer (NanoDrop Technologies) and an Agilent Bioanalyzer 2100 (Agilent Technologies Netherlands BV), respectively. Amino allyl-modified cDNA was synthesized using the Superscript III Reverse Transcriptase Kit (Invitrogen), purified with the CyScribe GFX purification kit (Amersham Biosciences) and labeled with Cy3- or Cy5-monoreactive dye (Amersham Biosciences). Labeled cDNA was purified with the CyScribe GFX purification kit (Amersham Biosciences). Labeled cDNA concentration and dye incorporation were assessed with a Nano Drop ND-1000 spectrophotometer. The labeled cDNA was hybridized to oligonucleotide microarrays in Ambion Slidehyb \#1 buffer (Ambion Europe Ltd) at $48^{\circ} \mathrm{C}$ for 18-20 hours. Next, microarray slides were washed for $5 \mathrm{~min}$ in $2 \times \mathrm{SSC}$ ( $300 \mathrm{mM} \mathrm{NaCl}, 30 \mathrm{mM}$ sodium citrate) with $0.5 \% \mathrm{SDS}$, twice for $5 \mathrm{~min}$ in $1 \times \mathrm{SSC}$ with $0.25 \%$ SDS and for $5 \mathrm{~min}$ in $1 \times$ SSC with $0.1 \%$ SDS, and dried by centrifugation. The slides were scanned with a GeneTac LS V confocal laser scanner (Genomic Solutions Ltd). ArrayPro 4.5 software (Media Cybernetics Inc., Silver Spring, Md., USA) was used to determine intensities of each spot on the microarrays using a local corners background correction method. Resulting expression levels were processed and normalized using the Lowess method with Micro-Prep [75]. The ln-transformed ratios of the expression levels were subject to a $t$-test using Cyber-T tool [76] resulting in expression ratios and Cyber-T (Bayesian) p values.

Table 4 Oligonucleotides used in this study

\begin{tabular}{|c|c|c|c|}
\hline Oligo name & Target & Sequence $^{a}\left(5^{\prime}-3^{\prime}\right)^{a}$ & Restriction enzyme site \\
\hline nprE-fw & nprE & CGCAAACCATGGGTTTAGGTAAGAAATTGTCTGTTGC & Ncol \\
\hline nprE-rv & nprE & GCGAAATCTAGATTAATGGTGATGGTGATGGTGCAATCCAACAGCATTCCAGGC & Xbal \\
\hline bla_F & bla & AAACCCTCATGAGTATTCAACATTTCCGTGTCG & Pagl \\
\hline bla_R & bla & ATACGCTCTAGATTAATGGTGATGGTGATGGTGCCAATGCTTAATCAGTG & Xbal \\
\hline ycdH-fw & $y c d H$ & GCGAAAGGTGACCGATATGTTTAAAAAATGGAGCGG & BstEll \\
\hline ycdH-rv & $y c d H$ & GCGAAATCTAGATTAATGGTGATGGTGATGGTGTGATTTAACCAATAGTGAATCTTTCAGGGC & Xbal \\
\hline$x y \mid P-f w$ & $x y / P$ & CGCATATCATGAGCGTTAGTATGCAGC & Pagl \\
\hline xylP-rv & $x y / P$ & GCGAAATCTAGATTAATGGTGATGGTGATGGTGCTITTGATCGTCAGCAA & Xbal \\
\hline
\end{tabular}

\footnotetext{
${ }^{a}$ Restriction enzyme sites are underlined.
} 


\section{SDS-PAGE and Western blotting}

In order to determine the subcellular localization of overproduced proteins XylP, LmrA, MntA, YcdH, XynA, NprE, Usp45 and TEM-1- $\beta$-lactamase (Bla) in B. subtilis, fractionation experiments were performed essentially as described before [18]. Cells were grown in TY medium. At the $\mathrm{OD}_{600}$ of 0.6 , protein production was induced by adding $0.1 \%$ subtilin containing supernatant of $B$. subtilis strain, ATCC $6633[7,73]$ and cultures were further incubated. After two hours, cells were collected by centrifugation $\left(4,000 \times \mathrm{g}, 4^{\circ} \mathrm{C}, 10 \mathrm{~min}\right)$, resuspended in protoplast buffer (PBS pH 7.2, $20 \mathrm{mM} \mathrm{MgCl}$, 20\% sucrose, $2 \mathrm{mg} / \mathrm{ml}$ lysozyme, and Complete protease inhibitors Roche) and incubated 30 minutes at $37^{\circ} \mathrm{C}$. Protoplasts were collected by centrifugation $\left(4,000 \times \mathrm{g}, 4^{\circ} \mathrm{C}, 10 \mathrm{~min}\right)$, resuspended in lysis buffer (50 mM Tris- $\mathrm{HCl}, \mathrm{pH} 8,2.5 \mathrm{mM}$ EDTA) and disrupted by sonication (Sonics Vibra Cell, Beun De Ronde). Unbroken protoplasts and cellular debris were removed by centrifugation $\left(4,000 \times \mathrm{g}, 4^{\circ} \mathrm{C}, 10 \mathrm{~min}\right)$. Supernatant was ultracentrifuged $\left(200,000 \times \mathrm{g}, 4^{\circ} \mathrm{C}, 30 \mathrm{~min}\right)$. The supernatant fraction containing cytosolic proteins was collected and an aliquot was used to prepare SDSPAGE samples. The pellet was resuspended in solubilization buffer $(20 \mathrm{mM}$ Tris- $\mathrm{HCl}, \mathrm{pH} 8.0,10 \%$ glycerol, $50 \mathrm{mM} \mathrm{NaCl}, 1 \%$ Triton-X-100) overnight on a rotor at $4{ }^{\circ} \mathrm{C}$. Nonsolubilized membranes were removed by ultracentrifugation $\left(100,000 \times \mathrm{g}, 4^{\circ} \mathrm{C}, 15 \mathrm{~min}\right)$. Supernatant with solubilized membrane proteins was collected and used for SDS-PAGE sample preparation.

The whole cell extracts were prepared as fallows. $1 \mathrm{OD}$ unit of a culture was collected by centrifugation, resuspended in $150 \mu \mathrm{l}$ of buffer containing $10 \mathrm{mM}$ Tris- $\mathrm{HCl} \mathrm{pH}$ 8.1, $20 \%$ sucrose, $10 \mathrm{mM}$ EDTA, $50 \mathrm{mM} \mathrm{NaCl}$ and $2 \mathrm{mg} / \mathrm{ml}$ lysozyme, and incubated at $37^{\circ} \mathrm{C}$ for $30 \mathrm{~min}$. An equal volume of $2 x$ SDS-PAGE sample buffer $(100 \mathrm{mM}$ Tris-HCl pH 6.8, 4\% SDS, 1\% DTT, 20\% glycerol, 0.05\% bromophenol blue) was added and the samples were boiled for $5 \mathrm{~min}$.

The extracellular proteins present in the medium were precipitated by adding $200 \mu \mathrm{l}$ of ice-cold 100\% TCA to $1.8 \mathrm{ml}$ of medium and incubation on ice for 1 hour. The mixture was centrifuged and the pellet was then washed with acetone, dried by air and resuspended in $100 \mu \mathrm{l} 1 \mathrm{x}$ SDS-PAGE sample buffer. Proteins from the whole cell extracts and the cell and medium fractions were separated on SDS-PAGE gels and transferred to a PVDF membrane. The immunodetection of His-tagged proteins was performed using the Penta-His HRP Conjugate Kit (Qiagen) and ECL detection reagents (Amersham).

\section{Additional file}

Additional file 1: Expression ratios of the $B$. subtilis genes under overproduction of different classes of proteins.

\section{Competing interests}

No competing interests are declared.

\section{Authors' contributions}

BCM contributed to the design of the study, has been involved in analysis and interpretation of data and writing the manuscript. HT and OPK conceived the study and have been involved in analysis and interpretation of data and writing the manuscript. BCM, HT, PvdV were involved in acquisition of data. OPK and HT were involved in the design of the study and have given final approval of the version to be published. All authors read and approved the final manuscript.

\section{Acknowledgements}

This research was supported by a grant from ALW-NWO in the ESF Bacell SysMO program and a Dutch TS grant from SenterNovem (Ministery of Economic Affairs) grant to HT and PvdV. We would like to thank Roland Hoffmann and Anna Marek for their contribution in data acquisition.

\section{Author details}

${ }^{1}$ Department of Molecular Genetics, Groningen Biomolecular Sciences and Biotechnology Institute, University of Groningen, Groningen, The Netherlands. ${ }^{2}$ Kluyver Center for Genomics of Industrial Fermentation, Delft/ Groningen, The Netherlands. ${ }^{3}$ Present address: Molecular Microbiology, Groningen Biomolecular Sciences and Biotechnology Institute, University of Groningen, Nijenborgh 7, 9747 AG, Groningen, The Netherlands. ${ }^{4}$ Institute for Life Science \& Technology, Hanze University Groningen of Applied Sciences, Zernikeplein 7, 9747 AS, Groningen, The Netherlands.

Received: 9 January 2012 Accepted: 5 May 2012

Published: 24 May 2012

\section{References}

1. Simonen M, Palva I: Protein secretion in Bacillus species. Microbiol Rev 1993, 57:109-137.

2. Tjalsma H, Bolhuis A, Jongbloed JD, Bron S, Van Dijl JM: Signal peptidedependent protein transport in Bacillus subtilis: a genome-based survey of the secretome. Microbiol Mol Biol Rev 2000, 64:515-547.

3. Westers L, Westers $H$, Quax WJ: Bacillus subtilis as cell factory for pharmaceutical proteins: a biotechnological approach to optimize the host organism. Biochimica et Biophysica Acta (BBA) - Mol Cell Res 2004, 1694:299-310

4. Westers L, Dijkstra DS, Westers H, van Dijl JM, Quax WJ: Secretion of functional human interleukin-3 from Bacillus subtilis. J Biotechnol 2006 123:211-224.

5. Wu S-C, Yeung JC, Duan Y, Ye R, Szarka SJ, Habibi HR, Wong S-L: Functional production and characterization of a fibrin-specific single-chain antibody fragment from Bacillus subtilis: effects of molecular chaperones and a wall-bound protease on antibody fragment production. Appl Environ Microbiol 2002, 68:3261-3269.

6. Wu XC, Lee W, Tran L, Wong SL: Engineering a Bacillus subtilis expressionsecretion system with a strain deficient in six extracellular proteases. J Bacteriol 1991, 173:4952-4958.

7. Bongers RS, Veening JW, Van Wieringen M, Kuipers OP, Kleerebezem M: Development and characterization of a subtilin-regulated expression system in Bacillus subtilis: strict control of gene expression by addition of subtilin. Appl Environ Microbiol 2005, 71:8818-8824

8. Joseph P, Fantino JR, Herbaud ML, Denizot F: Rapid orientated cloning in a shuttle vector allowing modulated gene expression in Bacillus subtilis. FEMS Microbiol Lett 2001, 205:91-97.

9. Kim L, Mogk A, Schumann W: A xylose-inducible Bacillus subtilis integration vector and its application. Gene 1996, 181:71-76.

10. Vitikainen M, Hyyrylainen HL, Kivimaki A, Kontinen VP, Sarvas M: Secretion of heterologous proteins in Bacillus subtilis can be improved by engineering cell components affecting post-translocational protein folding and degradation. J Appl Microbiol 2005, 99:363-375.

11. Wu S-C, Ye R, Wu X-C, Ng S-C, Wong S-L: Enhanced secretory production of a single-chain antibody fragment from Bacillus subtilis by coproduction of molecular chaperones. J Bacteriol 1998 180:2830-2835.

12. Pummi T, Leskelä S, Wahlström E, Gerth U, Tjalsma H, Hecker M, Sarvas M, Kontinen VP: ClpXP protease regulates the signal peptide cleavage of 
secretory preproteins in Bacillus subtilis with a mechanism distinct from that of the Ecs ABC transporter. J Bacterio/ 2002, 184:1010-1018.

13. Tjalsma H, Bolhuis A, van Roosmalen ML, Wiegert T, Schumann W, Broekhuizen CP, Quax WJ, Venema G, Bron S, van Dijl JM: Functional analysis of the secretory precursor processing machinery of Bacillus subtilis: identification of a eubacterial homolog of archaeal and eukaryotic signal peptidases. Genes Dev 1998, 12:2318-2331.

14. Thwaite JE, Baillie LWJ, Carter NM, Stephenson K, Rees M, Harwood CR, Emmerson PT: Optimization of the cell wall microenvironment allows increased production of recombinant Bacillus anthracis protective antigen from B. subtilis. Appl Environ Microbiol 2002, 68:227-234.

15. Hyyryläinen H-L, Vitikainen M, Thwaite J, Wu H, Sarvas M, Harwood CR, Kontinen VP, Stephenson K: d-Alanine substitution of teichoic acids as a modulator of protein folding and stability at the cytoplasmic membrane/cell wall interface of Bacillus subtilis. J Biol Chem 2000, 275:26696-26703.

16. Nijland R, Heerlien R, Hamoen LW, Kuipers OP: Changing a single amino acid in clostridium perfringens $\beta$-toxin affects the efficiency of heterologous secretion by Bacillus subtilis. Appl Environ Microbiol 2007, 73:1586-1593.

17. Brockmeier U, Caspers M, Freudl R, Jockwer A, Noll T, Eggert T: Systematic screening of all signal peptides from Bacillus subtilis: a powerful strategy in optimizing heterologous protein secretion in Gram-positive bacteria. J Mol Biology 2006, 362:393-402.

18. Zweers JC, Wiegert T, van Dijl JM: Stress-responsive systems set specific limits to the overproduction of membrane proteins in Bacillus subtilis. Appl Environ Microbiol 2009, 75:7356-7364

19. Zweers JC, Barak I, Becher D, Driessen AJ, Hecker M, Kontinen VP, Saller MJ, Vavrova L, van Dijl JM: Towards the development of Bacillus subtilis as a cell factory for membrane proteins and protein complexes. Microb Cell Fact 2008, 7:10.

20. van Veen HW, Venema K, Bolhuis H, Oussenko I, Kok J, Poolman B, Driessen AJ, Konings WN: Multidrug resistance mediated by a bacterial homolog of the human multidrug transporter MDR1. Proc Natl Acad Sci U S A 1996 93:10668-10672.

21. Heuberger EHML, Smits E, Poolman B: Xyloside transport by XyIP, a member of the galactoside-pentoside-hexuronide family. J Biological Chemistry 2001, 276:34465-34472.

22. Que Q, Helmann JD: Manganese homeostasis in Bacillus subtilis is regulated by $M n t R$, a bifunctional regulator related to the diphtheria toxin repressor family of proteins. Mol Microbiol 2000, 35:1454-1468.

23. Gaballa A, Helmann JD: Identification of a zinc-specific metalloregulatory protein, Zur, controlling zinc transport operons in Bacillus subtilis. J Bacteriol 1998, 180:5815-5821.

24. Papagiannitsis CC, Tzouvelekis LS, Kotsakis SD, Tzelepi E, Miriagou V: Sequence of pR3521, an IncB plasmid from Escherichia coli encoding ACC-4, SCO-1, and TEM-1 $\beta$-lactamases. Antimicrob Agents Chemother 2011, 55:376-381.

25. van Asseldonk M, Rutten G, Oteman M, Siezen RJ, de Vos WM, Simons G: Cloning of usp45, a gene encoding a secreted protein from Lactococcus lactis subsp. lactis MG1363. Gene 1990, 95:155-160.

26. Stephenson K, Bron S, Harwood CR: Cellular lysis in Bacillus subtilis; the affect of multiple extracellular protease deficiencies. Lett Appl Microbiol 1999, 29:141-145

27. Kikuchi M, Ogawa K, Yamazaki T, Kajiwara S, Sugio A, Nakamura S, Shishido K: Secretional expression of a Bacillus subtilis xylanase gene in the Basidiomycete Coprinus cinereus. FEMS Microbiol Lett 1999, 178:277-282.

28. Bolhuis A, Tjalsma H, Smith HE, de Jong A, Meima R, Venema G, Bron S, van Dijl JM: Evaluation of bottlenecks in the late stages of protein secretion in Bacillus subtilis. Appl Environ Microbiol 1999, 65:2934-2941.

29. Maruyama F, Kobata M, Kurokawa K, Nishida K, Sakurai A, Nakano K, Nomura R, Kawabata S, Ooshima T, Nakai K, Hattori M, Hamada S, Nakagawa I: Comparative genomic analyses of Streptococcus mutans provide insights into chromosomal shuffling and species-specific content. BMC Genomics 2009, 10:358

30. Siezen RJ, Bayjanov J, Renckens B, Wels M, van Hijum SAFT, Molenaar D, van Hylckama Vlieg JET: Complete genome sequence of Lactococcus lactis subsp. lactis KF147, a plant-associated lactic acid bacterium. J Bacterio 2010, 192:2649-2650.

31. Reichmann $P$, Nuhn $M$, Denapaite $D$, Brückner $R$, Henrich B, Maurer $P$, Rieger $M$, Klages S, Reinhard R, Hakenbeck R: Genome of Streptococcus oralis strain Uo5. J Bacteriol 2011, 193:2888-2889.
32. Derré I, Rapoport G, Msadek T: CtsR, a novel regulator of stress and heat shock response, controls $c / p$ and molecular chaperone gene expression in gram-positive bacteria. Mol Microbiol 1999, 31:117-131.

33. Hecker M, Schumann W, Volker U: Heat-shock and general stress response in Bacillus subtilis. Mol Microbiol 1996, 19:417-428.

34. Krüger E, Witt E, Ohlmeier S, Hanschke R, Hecker M: The Clp proteases of Bacillus subtilis are directly involved in degradation of misfolded proteins. J Bacteriol 2000, 182:3259-3265.

35. Mogk A, Völker A, Engelmann S, Hecker M, Schumann W, Völker U: Nonnative proteins induce expression of the Bacillus subtilis CIRCE regulon. J Bacteriol 1998, 180:2895-2900.

36. Moch C, Schrögel O, Allmansberger R: Transcription of the $n f r A-y w c H$ operon from Bacillus subtilis is specifically induced in response to heat. J Bacteriol 2000, 182:4384-4393.

37. Tam LT, Antelmann H, Eymann C, Albrecht D, Bernhardt J, Hecker M: Proteome signatures for stress and starvation in Bacillus subtilis as revealed by a 2-D gel image color coding approach. Proteomics 2006, 6:4565-4585.

38. Fujisawa $M$, Wada $Y$, Ito $M$ : Modulation of the $K$ + efflux activity of Bacillus subtilis YhaU by YhaT and the C-terminal region of YhaS. FEMS Microbiol Lett 2004, 231:211-217.

39. Cao M, Kobel PA, Morshedi MM, Wu MFW, Paddon C, Helmann JD: Defining the Bacillus subtilis sigma(W) regulon: a comparative analysis of promoter consensus search, run-off transcription/macroarray analysis (ROMA), and transcriptional profiling approaches. J Mol Biol 2002, 316:443-457.

40. Petersohn A, Brigulla M, Haas S, Hoheisel JD, Völker U, Hecker M: Global analysis of the general stress response of Bacillus subtilis. J Bacterio/ 2001, 183:5617-5631.

41. Nakano S, Küster-Schöck E, Grossman AD, Zuber P: Spx-dependent global transcriptional control is induced by thiol-specific oxidative stress in Bacillus subtilis. Proc Natl Acad Sci U S A 2003, 100:13603-13608.

42. Ellermeier CD, Hobbs EC, Gonzalez-Pastor JE, Losick R: A three-protein signaling pathway governing immunity to a bacterial cannibalism toxin. Cell 2006, 124:549-559.

43. Engelberg-Kulka H, Amitai S, Kolodkin-Gal I, Hazan R: Bacteria programmed cell death and multicellular behavior in bacteria. PLOS Genet. 2006, 2:e135.

44. Liu X, Taber HW: Catabolite regulation of the Bacillus subtilis ctaBCDEF gene cluster. J Bacteriol 1998, 180:6154-6163.

45. Westers H, Westers L, Darmon E, van Dijl JM, Quax WJ, Zanen G: The CssRS two-component regulatory system controls a general secretion stress response in Bacillus subtilis. FEBS J 2006, 273:3816-3827.

46. Darmon E, Noone D, Masson A, Bron S, Kuipers OP, Devine KM, van Dijl JM: A novel class of heat and secretion stress-responsive genes is controlled by the autoregulated CssRS two-component system of Bacillus subtilis. J Bacteriol 2002, 184:5661-5671.

47. Antelmann H, Darmon E, Noone D, Veening J, Westers H, Bron S, Kuipers OP, Devine KM, Hecker M, Van Dijl JM: The extracellular proteome of Bacillus subtilis under secretion stress conditions. Mol Microbiol 2003, 49:143-156.

48. Trip H, van der Veek PJ, Renniers TC, Meima R, Sagt CM, Mohrmann L, Kuipers OP: A novel screening system for secretion of heterologous proteins in Bacillus subtilis. Microb Biotechnol 2011, 4:673-682.

49. Noone D, Howell A, Devine KM: Expression of $y k d A$, encoding a Bacillus subtilis homologue of $\mathrm{Htr} A$, is heat shock inducible and negatively autoregulated. J Bacteriol 2000, 182:1592-1599.

50. Wolf D, Kalamorz F, Wecke T, Juszczak A, Mäder U, Homuth G, Jordan S, Kirstein J, Hoppert M, Voigt B, Hecker M, Mascher T: In-depth profiling of the LiaR response of Bacillus subtilis. J Bacteriol 2010, 192:4680-4693.

51. Cao M, Wang T, Ye R, Helmann JD: Antibiotics that inhibit cell wall biosynthesis induce expression of the Bacillus subtilis sigma(W) and sigma(M) regulons. Mol Microbiol 2002, 45:1267-1276.

52. Mascher T, Margulis NG, Wang T, Ye RW, Helmann JD: Cell wall stress responses in Bacillus subtilis: the regulatory network of the bacitracin stimulon. Mol Microbiol 2003, 50:1591-1604

53. Mascher T, Zimmer SL, Smith T-A, Helmann JD: Antibiotic-inducible promoter regulated by the cell envelope stress-sensing two-component system LiaRS of Bacillus subtilis. Antimicrob Agents Chemother 2004 48:2888-2896

54. Jordan S, Hutchings MI, Mascher T: Cell envelope stress response in Grampositive bacteria. FEMS Microbiol Rev 2008, 32:107-146. 
55. Wiegert T, Homuth G, Versteeg S, Schumann W: Alkaline shock induces the Bacillus subtilis sigma(W) regulon. Mol Microbiol 2001, 41:59-71.

56. Ellermeier CD, Losick R: Evidence for a novel protease governing regulated intramembrane proteolysis and resistance to antimicrobial peptides in Bacillus subtilis. Genes Dev 2006, 20:1911-1922.

57. Heinrich J, Wiegert T: Regulated intramembrane proteolysis in the control of extracytoplasmic function sigma factors. Res Microbiol 2009, 160:696-703.

58. Sakoh M, Ito K, Akiyama Y: Proteolytic activity of HtpX, a membranebound and stress-controlled protease from Escherichia coli. J Biol Chem 2005, 280:33305-33310.

59. Shimohata N, Chiba S, Saikawa N, Ito K, Akiyama Y: The Cpx stress response system of Escherichia coli senses plasma membrane proteins and controls $\mathrm{HtpX}$, a membrane protease with a cytosolic active site. Genes to Cells 2002, 7:653-662.

60. Akiyama Y: Quality control of cytoplasmic membrane proteins in Escherichia coli. J Biochem 2009, 146:449-454.

61. Cutting S, Anderson M, Lysenko E, Page A, Tomoyasu T, Tatematsu K, Tatsuta T, Kroos L, Ogura T: SpoVM, a small protein essential to development in Bacillus subtilis, interacts with the ATP-dependent protease FtsH. J Bacteriol 1997, 179:5534-5542.

62. Le ATT, Schumann W: The Spo0E phosphatase of Bacillus subtilis is a substrate of the FtsH metalloprotease. Microbiology 2009, 155:1122-1132.

63. Thackray PD, Moir A: SigM, an extracytoplasmic function sigma factor of Bacillus subtilis, is activated in response to cell wall antibiotics, ethanol, heat, acid, and superoxide stress. J Bacteriol 2003, 185:3491-3498.

64. Cao M, Moore CM, Helmann JD: Bacillus subtilis paraquat resistance is directed by sigma(M), an extracytoplasmic function sigma factor, and is conferred by YqjL and BcrC. J Bacterio/ 2005, 187:2948-2956.

65. Jervis AJ, Thackray PD, Houston CW, Horsburgh MJ, Moir A: SigM-responsive genes of Bacillus subtilis and their promoters. J Bacteriol 2007, 189:4534-4538.

66. Cao M, Salzberg L, Tsai CS, Mascher T, Bonilla C, Wang T, Ye RW, MárquezMagaña L, Helmann JD: Regulation of the Bacillus subtilis extracytoplasmic function protein sigma(Y) and its target promoters. J Bacterio/ 2003, 185:4883-4890.

67. Kuipers OP, de Ruyter PGGA, Kleerebezem M, de Vos WM: Quorum sensing-controlled gene expression in lactic acid bacteria. J Biotechnol 1998, 64:15-21.

68. Killmann H, Herrmann C, Torun A, Jung G, Braun V: TonB of Escherichia coli activates FhuA through interaction with the $\beta$-barrel. Microbiology 2002, 148:3497-3509.

69. Holo H, Nes IF: Transformation of Lactococcus by electroporation. Methods Mol Biol 1995, 47:195-199.

70. Kunst F, Rapoport G: Salt stress is an environmental signal affecting degradative enzyme synthesis in Bacillus subtilis. J Bacteriol 1995, 177:2403-2407.

71. Sambrook J, Fritsch EF, Maniatis T: Molecular Cloning: A Laboratory Manual. Cold Spring Harbor, NY, USA: Cold Spring Harbor laboratory Pres; 1989.

72. Vieira J, Messing J: The pUC plasmids, an M13mp7-derived system for insertion mutagenesis and sequencing with synthetic universal primers. Gene 1982, 19:259-268.

73. Duitman EH, Hamoen LW, Rembold M, Venema G, Seitz H, Saenger W, Bernhard F, Reinhardt R, Schmidt M, Ullrich C, Stein T, Leenders F, Vater J: The mycosubtilin synthetase of Bacillus subtilis ATCC6633: a multifunctional hybrid between a peptide synthetase, an amino transferase, and a fatty acid synthase. Proc Natl Acad Sci U S A 1999, 96:13294-13299.

74. Lulko AT, Buist G, Kok J, Kuipers OP: Transcriptome analysis of temporal regulation of carbon metabolism by $\mathrm{CcpA}$ in Bacillus subtilis reveals additional target genes. J Mol Microbiol Biotechnol 2007, 12:82-95.

75. Van Hijum SAFT, García De La Nava J, Trelles O, Kok J, Kuipers OP, MicroPreP: a cDNA microarray data pre-processing framework. Appl Bioinformatics 2003, 2:241-244.

76. Long AD, Mangalam HJ, Chan BY, Tolleri L, Hatfield GW, Baldi P: Improved statistical inference from DNA microarray data using analysis of variance and a Bayesian statistical framework. Analysis of global gene expression in Escherichia coli K12. J Biol Chem 2001, 276:19937-19944.

doi:10.1186/1475-2859-11-66

Cite this article as: Marciniak et al.: Comparative transcriptional analysis of Bacillus subtilis cells overproducing either secreted proteins, lipoproteins or membrane proteins. Microbial Cell Factories 2012 11:66.

\section{Submit your next manuscript to BioMed Central and take full advantage of:}

- Convenient online submission

- Thorough peer review

- No space constraints or color figure charges

- Immediate publication on acceptance

- Inclusion in PubMed, CAS, Scopus and Google Scholar

- Research which is freely available for redistribution 